Nevada

Environmental

Management

Operations Activity

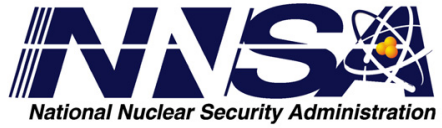

Addendum to the

Corrective Action Decision Document/

Closure Report for Corrective Action

Unit 529: Area 25 Contaminated

Materials, Nevada Test Site, Nevada

Controlled Copy No.:

Revision No.: 1

October 2013

UNCLASSIFIED

/s/ Joseph P. Johnston

Joseph P. Johnston, N-I CO

$10 / 22 / 2013$

Date

Approved for public release; further dissemination unlimited.

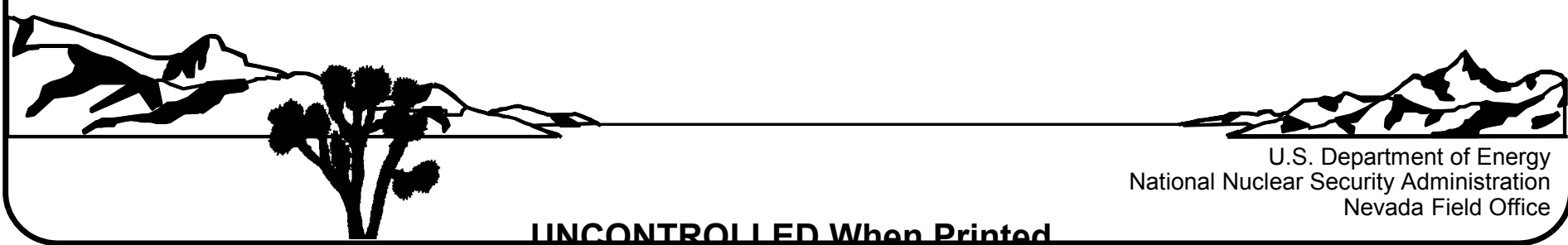


Available for sale to the public from:

U.S. Department of Commerce

National Technical Information Service

5301 Shawnee Road

Alexandria, VA 22312

Telephone: 800.553 .6847

Fax: 703.605.6900

E-mail: orders@ntis.gov

Online Ordering: http://www.ntis.gov/help/ordermethods.aspx

Available electronically at http://www.osti.gov/bridge

Available for a processing fee to U.S. Department of Energy and its contractors, in paper, from:

U.S. Department of Energy

Office of Scientific and Technical Information

P.O. Box 62

Oak Ridge, TN 37831-0062

Phone: 865.576 .8401

Fax: 865.576.5728

Email: reports@adonis.osti.gov

Reference herein to any specific commercial product, process, or service by trade name, trademark, manufacturer, or otherwise, does not necessarily constitute or imply its endorsement, recommendation, or favoring by the United States Government or any agency thereof or its contractors or subcontractors. 


\section{ADDENDUM TO THE CORRECTIVE ACTION DECISION DOCUMENT/CLOSURE REPORT FOR CORRECTIVE ACTION UNIT 529: AREA 25 CONTAMINATED MATERIALS, NEVADA TEST SITE, NEVADA}

U.S. Department of Energy, National Nuclear Security Administration

Nevada Field Office

Las Vegas, Nevada

Controlled Copy No.:

Revision No.: 1

October 2013

Approved for public release; further dissemination unlimited. 


\section{ADDENDUM TO THE CORRECTIVE ACTION DECISION DOCUMENT/ CLOSURE REPORT FOR CORRECTIVE ACTION UNIT 529: AREA 25 CONTAMINATED MATERIALS, NEVADA TEST SITE, NEVADA}

\footnotetext{
Approved by: /s/ Tiffany A. Lantow Tiffany A. Lantow Industrial Sites Activity Lead
}

Date:

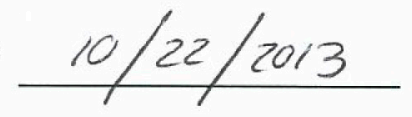

\footnotetext{
Approved by: $\frac{\text { /S/ Robert F. Boehlecke Date: } 10 / 22 / 13}{\text { Robert F. Boehlecke }}$ Environmental Management Operations Manager
} 


\section{Addendum to the Closure Report for Removal of the Use Restriction}

This document constitutes an addendum to the Corrective Action Decision Document/Closure Report for Corrective Action Unit 529: Area 25 Contaminated Materials, Nevada Test Site, Nevada (NNSA/NSO, 2004) as described in the document Recommendations and Justifications To Remove Use Restrictions Established under the U.S. Department of Energy, National Nuclear Security Administration Nevada Field Office Federal Facility Agreement and Consent Order (FFACO) dated September 2013. The Use Restriction (UR) Removal document was approved by the Nevada Division of Environmental Protection (NDEP) on October 16, 2013. The approval of the UR Removal document constituted approval of each of the recommended UR removals. In conformance with the UR Removal document, this addendum consists of:

- This page that refers the reader to the UR Removal document for additional information

- The cover, title, and signature pages of the UR Removal document

- The NDEP approval letter

- The corresponding section of the UR Removal document

This addendum provides the documentation justifying the cancellation of the UR for CAS 25-23-17, Contaminated Wash (Parcel H). This UR was established as part of FFACO (FFACO, 1996; as amended) corrective actions and was based on the presence of total petroleum hydrocarbon diesel-range organics (TPH-DRO) contamination at concentrations greater than the NDEP action level at the time of the initial investigation.

Since this UR was established, practices and procedures relating to the implementation of risk-based corrective actions (RBCA) have changed. Therefore, this UR was re-evaluated against the current RBCA criteria as defined in the Soils Risk-Based Corrective Action Evaluation Process (NNSA/NSO, 2012). This re-evaluation consisted of collecting new volatile organic compound (VOC) and semivolatile organic compound (SVOC) samples from previous sample locations and depths that had the highest TPH-DRO concentrations. The VOC and SVOC results were compared to the current Industrial Area U.S. Environmental Protection Agency regional screening levels (RSL). The hazardous constituents of TPH-DRO were not detected in any of the samples at concentrations greater than their respective RSLs; therefore, no contaminants are present at this site in concentrations exceeding the FALs.

The re-evaluation resulted in a recommendation to remove this UR because contamination is not present at this site above the risk-based FAL. Requirements for inspecting and maintaining this UR will be canceled, and the fencing and signage associated with the UR will be removed. This modification will not affect or modify any non-FFACO requirements for fencing, posting, or monitoring at this site. 


\section{References}

EPA, see U.S. Environmental Protection Agency.

FFACO, see Federal Facility Agreement and Consent Order.

Federal Facility Agreement and Consent Order. 1996 (as amended March 2010). Agreed to by the State of Nevada; U.S. Department of Energy, Environmental Management; U.S. Department of Defense; and U.S. Department of Energy, Legacy Management. Appendix VI, which contains the Industrial Sites Strategy, was last modified May 2011, Revision No. 4.

NAC, see Nevada Administrative Code.

Nevada Administrative Code. 2008. NAC 445A.2272, “Contamination of Soil: Establishment of Action Levels." Carson City, NV.

NNSA/NFO, see U.S. Department of Energy, National Nuclear Security Administration Nevada Field Office.

NNSA/NSO, see U.S. Department of Energy, National Nuclear Security Administration Nevada Site Office.

U.S. Department of Energy, National Nuclear Security Administration Nevada Field Office. 2013. Recommendations and Justifications To Remove Use Restrictions Established under the U.S. Department of Energy, National Nuclear Security Administration Nevada Field Office Federal Facility Agreement and Consent Order, Rev. 0, DOE/NV--1510. Las Vegas, NV.

U.S. Department of Energy, National Nuclear Security Administration Nevada Site Office. 2004. Corrective Action Decision Document/Closure Report for Corrective Action Unit 529: Area 25 Contaminated Materials, Nevada Test Site, Nevada, Rev. 1, DOE/NV--1000--REV. 1. Las Vegas, NV.

U.S. Department of Energy, National Nuclear Security Administration Nevada Site Office. 2012. Soils Risk-Based Corrective Action Evaluation Process, Rev. 0, DOE/NV--1475. Las Vegas, NV.

U.S. Environmental Protection Agency. 2013. Pacific Southwest, Region 9: Regional Screening Levels (Formerly PRGs), Screening Levels for Chemical Contaminants. As accessed at http://www.epa.gov/region9/superfund/prg/ on 11 February. Prepared by EPA Office of Superfund and Oak Ridge National Laboratory. 
Nevada

Environmental

Management

Operations Activity

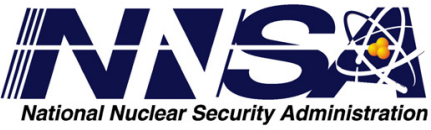

Recommendations and Justifications

To Remove Use Restrictions Established

under the U.S. Department of Energy,

National Nuclear Security Administration

Nevada Field Office

Federal Facility Agreement

and Consent Order

Controlled Copy No.: _

Revision No.: 0

September 2013

UNCLASSIFIED

Is/ Joseph P. Johnston, N-I CO 09/09/2013

Approved for public release; further dissemination unlimited.
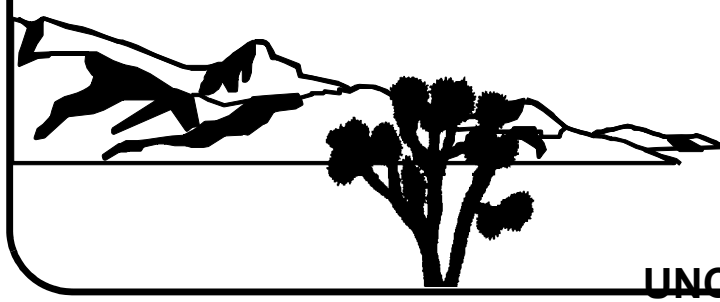
Available for sale to the public from:

U.S. Department of Commerce

National Technical Information Service

5301 Shawnee Road

Alexandria, VA 22312

Telephone: 800.553 .6847

Fax: 703.605.6900

E-mail: orders@ntis.gov

Online Ordering: http://www.ntis.gov/help/ordermethods.aspx

Available electronically at http://www.osti.gov/bridge

Available for a processing fee to U.S. Department of Energy and its contractors, in paper, from:

U.S. Department of Energy

Office of Scientific and Technical Information

P.O. Box 62

Oak Ridge, TN 37831-0062

Phone: 865.576 .8401

Fax: 865.576.5728

Email: reports@adonis.osti.gov

Reference herein to any specific commercial product, process, or service by trade name, trademark, manufacturer, or otherwise, does not necessarily constitute or imply its endorsement, recommendation, or favoring by the United States Government or any agency thereof or its contractors or subcontractors. 


\title{
RECOMMENDATIONS AND JUSTIFICATIONS TO REMOVE USE RESTRICTIONS ESTABLISHED UNDER THE U.S. DEPARTMENT OF ENERGY, NATIONAL NUCLEAR SECURITY ADMINISTRATION NEVADA FIELD OFFICE FEDERAL FACILITY AGREEMENT AND CONSENT ORDER
}

\author{
U.S. Department of Energy, National Nuclear Security Administration \\ Nevada Field Office \\ Las Vegas, Nevada
}

Controlled Copy No.:

Revision No.: 0

September 2013

Approved for public release; further dissemination unlimited. 


\subsection{CAU 529, CAS 25-23-17 - Contaminated Wash (Parcel H)}

\subsection{CAS Description}

CAS 25-23-17, Contaminated Wash, is the only CAS in CAU 529 and is located in Area 25 of the NNSS. The CAS was divided into nine parcels because of the large area impacted by past operations and the complexity of the source areas. The CAS was subdivided into separate parcels based on separate and distinct releases as determined and approved in the DQO process and Corrective Action Investigation Plan (NNSA/NSO, 2003).

Parcel H, contaminated soil storage area, consists of the area west of Test Cell $\mathrm{C}$ within the wash and immediately south of the berm. Contaminated soil associated with the Phoebus 1A Test was stored in a pile on the floor of the wash and sprayed with oil to prevent wind erosion. The soil pile was eventually moved, and 2,340 cubic yards of contaminated soil was disposed of at the Area 3 Radioactive Waste Management Site (NNSA/NSO, 2004a).

During closure activities, a wire fence was installed around the entire area of TPH-DRO contamination with concentrations exceeding the $100 \mathrm{mg} / \mathrm{kg}$ NAC action level, and UR signs were posted (NNSA/NSO, 2004a).

\subsection{Current UR Description}

The future use of any land related to this CAU is restricted from any DOE or U.S. Department of Defense (DoD) activity that may alter or modify the containment control as approved by the State of Nevada and identified in the CAU CR or other CAU documentation unless appropriate concurrence is obtained in advance.

The post-closure inspections of the Parcel H UR consist of annual visual inspections. Visual inspections of the wire fence, T-posts, and signage are conducted to verify that they are intact, undisturbed, and in good condition (NNSA/NSO, 2004a). 


\subsection{Basis for Current UR}

Surface and subsurface soil samples were analyzed for SVOCs, PCBs, TPH-DRO, beryllium, RCRA metals, gamma spectroscopy, isotopic U, and Sr-90. The analytical results at five sample locations exceeded the TPH-DRO PAL of $100 \mathrm{mg} / \mathrm{kg}$. Although the radionuclides cesium (Cs)-137 and U-234 exceeded their respective PALs, a risk assessment was conducted to determine whether the presence of the radiological site contamination posed an unacceptable risk to human health and the environment. The radiological contamination identified in Parcel $\mathrm{H}$ is below the FAL for unrestricted industrial reuse for Cs-137 and U-234, and therefore does not pose an unacceptable risk. All other constituents had results below PALs. Table 5-1 contains analytical results for TPH-DRO at CAS 25-23-17 (Parcel H) that are the basis for the current UR. The sample matrix for all samples is soil.

Table 5-1

Sample Results for TPH-DRO at CAS 25-23-17 (Parcel H) Used To Establish Current UR

\begin{tabular}{|c|c|c|c|}
\hline \multirow{2}{*}{$\begin{array}{c}\text { Sample } \\
\text { Location }\end{array}$} & Sample ID & $\begin{array}{c}\text { Depth } \\
\text { (ft bgs) }\end{array}$ & $\begin{array}{c}\text { PAL } \\
100 ~ \mathbf{~ g} / \mathbf{k g}\end{array}$ \\
\hline \hline $\mathrm{H} 01$ & $529 \mathrm{H} 007$ & $0.0-0.5$ & $240(\mathrm{H}, \mathrm{M})$ \\
\hline $\mathrm{H} 02$ & $529 \mathrm{H} 005$ & $0.0-0.5$ & $7,900(\mathrm{~J})^{\mathrm{a}}$ \\
\hline $\mathrm{H} 08$ & $529 \mathrm{H} 006$ & $2.0-3.0$ & $260(\mathrm{H}, \mathrm{M})$ \\
\hline $\mathrm{H} 10$ & $529 \mathrm{H} 017$ & $0.0-0.5$ & $580(\mathrm{H}, \mathrm{M})$ \\
\hline $\mathrm{H} 13$ & $529 \mathrm{H} 021$ & $1.5-2.0$ & $300(\mathrm{H}, \mathrm{M})$ \\
\hline
\end{tabular}

${ }^{a}$ Qualifier added to laboratory data; record accepted. Surrogates diluted out.

$\mathrm{H}=$ Fuel pattern was in the heavier end of the retention time window for the analyte of interest. $\mathrm{M}=\mathrm{A}$ pattern resembling motor oil was detected.

$\mathrm{J}=$ Estimated value

The PALs for all radioisotopes, except those covered by DOE Order 5400.5 (DOE, 1993), were derived from the construction, commercial, industrial land-use scenario in Table 2.1 of the NCRP Report No. 129 (NCRP, 1999). The values provided in this source document are based on a $25-\mathrm{mem} / \mathrm{yr}$ dose but were scaled to a $15-\mathrm{mrem} / \mathrm{yr}$ dose for this corrective action investigation. 


\subsection{Basis for UR Modification}

The samples were analyzed only for TPH-DRO and SVOCs, but not VOCs. There are no Tier 2 FALs for TPH, and total TPH concentrations are not used for risk-based decisions under Tier 2 or Tier 3. Rather, the individual hazardous constituents of TPH (e.g., VOCs and SVOCs) are compared to the Tier 2 SSTLs; however, there were no VOC results to compare to PAL or to conduct Tier 2 evaluations.

In July 2013, samples were collected at Parcel $\mathrm{H}$ at the five previous sample locations and depths that had the highest TPH-DRO concentrations. These samples were analyzed for TPH-DRO, VOCs, and SVOCs. The TPH-DRO concentrations ranged from 1.8 to $24 \mathrm{mg} / \mathrm{kg}$. The VOC and SVOC concentrations were compared to the IA EPA RSLs; none of the results exceed the RSLs, and the FALs were established at the PAL concentrations.

\subsection{Proposed Modification}

Remove the FFACO UR, associated wire fencing and postings, and annual inspection and maintenance requirements from this site. The previous sample locations at Parcel $\mathrm{H}$ with the highest TPH-DRO concentrations were resampled and analyzed for TPH-DRO, VOCs, and SVOCs; the concentrations did not exceed the FALs. These modifications will not affect or modify any non-FFACO requirements at this site. 
DOE, see U.S. Department of Energy.

NCRP, see National Council on Radiation Protection and Measurements.

NNSA/NSO, see U.S. Department of Energy, National Nuclear Security Administration Nevada Site Office.

National Council on Radiation Protection and Measurements. 1999. Recommended Screening Limits for Contaminated Surface Soil and Review of Factors Relevant to Site-Specific Studies, NCRP Report No. 129. Bethesda, MD.

U.S. Department of Energy. 1993. Radiation Protection of the Public and the Environment, DOE Order 5400.5, Change 2. Washington, DC.

U.S. Department of Energy, National Nuclear Security Administration Nevada Site Office. 2003. Corrective Action Investigation Plan for Corrective Action Unit 529: Area 25 Contaminated Materials, Nevada Test Site, Nevada, Rev. 0, DOE/NV--870. Las Vegas, NV.

U.S. Department of Energy, National Nuclear Security Administration Nevada Site Office. 2004a. Corrective Action Decision Document/Closure Report for Corrective Action Unit 529: Area 25 Contaminated Materials, Nevada Test Site, Nevada, Rev. 1, DOE/NV--1000--REV. 1. Las Vegas, NV. 


\title{
Library Distribution List
}

\author{
$\underline{\text { Copies }}$ \\ U.S. Department of Energy \\ 1 (Uncontrolled, electronic copy) \\ Office of Scientific and Technical Information \\ P.O. Box 62 \\ Oak Ridge, TN 37831-0062 \\ Southern Nevada Public Reading Facility \\ 2 (Uncontrolled, electronic copies) \\ c/o Nuclear Testing Archive \\ P.O. Box 98521, M/S 400 \\ Las Vegas, NV 89193-8521 \\ Manager, Northern Nevada FFACO \\ 1 (Uncontrolled, electronic copy) \\ Public Reading Facility \\ c/o Nevada State Library \& Archives \\ 100 N. Stewart Street \\ Carson City, NV 89701-4285
}

